\title{
EM BUSCA DE UMA IDEOLOGIA PARA A REVOLUÇÃO MEXICANA
}

\author{
Ana Paula Cantarelli ${ }^{1}$ \\ Erivelton Franco de Lima ${ }^{2}$
}

Resumo: Vários pesquisadores, desde 1910, teceram reflexões sobre a existência ou não de uma ideologia manifesta na estrutura da revolução mexicana. Neste texto, dedicamo-nos a retomar de forma breve tais discussões a partir da análise do romance Pedro Páramo, de Juan Rulfo. Nosso intuito é apresentar uma proposta de leitura dessa obra considerando, principalmente, os estudos de Octavio Paz (1998) e Arnaldo Córdova (1989 e 2003) que possuem perspectivas distintas sobre esse tema.

Palavras-chave: revolução; ideologias; Modernidade; Pedro Páramo.

Resumen: Muchos investigadores, desde 1910, reflexionaron sobre la existencia o no de una ideología en la estructura de la revolución mexicana. En este texto, recuperamos algunas de esas reflexiones desde el análisis de la novela Pedro Páramo, de Juan Rulfo. Nuestra intención es presentar una propuesta de lectura de esa obra llevando en consideración, principalmente, los estudios de Octavio Paz (1998) y de Arnaldo Córdova (1989 e 2003) que poseen perspectivas distintas acerca de ese tema.

Palabras clave: revolución; ideologías; Modernidad; Pedro Páramo.

\footnotetext{
1 Professora do Curso de Letras - Espanhol da Universidade Federal de Rondônia (UNIR). Pós-doutoranda do Programa de Pós-Graduação em Literatura, da Universidade de Brasília (UnB). E-mail: anapaula.cantarelli@gmail.com.

2 Professor de Língua e Literatura Espanholas. Aluno do curso de Especialização em Ensino de Espanhol, do Instituto Prominas. E-mail: erivelton_franco@yahoo.com.br.
} 


\section{CONSIDERAÇÕES INICIAIS}

Em 1955, o mexicano Juan Rulfo publicou seu primeiro - e único - romance: Pedro Páramo. Antes dele, o autor só havia tido mais um livro publicado: El llano en llamas (1953), uma seleção de contos que trata da identidade mexicana e do processo revolucionário, enfatizando aspectos relacionados ao clima e à paisagem nacionais. Pedro Páramo é considerado uma das obras mais importantes da literatura produzida na América Latina e, inclusive, da literatura mundial, acumulando sobre si uma série de estudos vinculados a diferentes áreas do saber (história, filosofia, literatura, sociologia, etc.). Rulfo, em diversas entrevistas, afirmou que esse romance é fruto de um longo período de reflexão e de planejamento que se iniciou com uma ideia formada antes de seus trinta anos ${ }^{3}$. O escritor ainda declarou que os contos de El llano en llamas foram uma maneira de aproximar-se do romance que estava delineando:

Tenía los personajes completos de Pedro Páramo, sabía que iba a ubicarlos en un pueblo abandonado, desértico; tenía totalmente elaborada la novela, lo que me faltaba eran ciertas formas para poder decirlo. Y para eso escribí los cuentos: ejercicios sobre diversos temas, a veces poco desarrollados, buscando soltar la mano, encontrar la forma de la novela. ${ }^{4}$ (RULFO, 1996, p. 463)

Pedro Páramo, em seu enredo, traz diversos elementos que remetem ao processo revolucionário mexicano ocorrido entre 1910 e $1920^{5}$. Entretanto, diferentemente do grande número de produções literárias que se encontram vinculadas a tal temática, o texto rulfiano abandona o caráter testemunhal e debruça-se sobre questões mais profundas que remetem à constituição identitária mexicana revolvendo referências mitológicas que remontam aos grupos indígenas que habitavam as terras que foram invadidas pelos espanhóis. Rulfo usa personagens mortos e um povoado abandonado para unir séculos de história nas pouco mais de cem páginas de seu romance, apresentando ao seu leitor uma visão histórica que exige que presente e passado sejam amarrados em busca de uma possível construção de futuro.

Apesar do abandono da versão testemunhal, Pedro Páramo não deixa de conceder um grande destaque à revolução enquanto elemento histórico. Segundo Carlos Fuentes (1980, p. 16), o romance de Rulfo encerrou "para siempre - y con llave de oro - la temática

\footnotetext{
3 Em junho de 1947, quando acabara de completar 30 anos, Rulfo mencionou em uma carta sua intenção de escrever um romance sob o título de Una estrella junto a la luna (VITAL, 2003).

4 Tradução nossa: “Tinha as personagens completas de Pedro Páramo, sabia que ia situá-las em um povoado abandonado, desértico; tinha elaborado completamente o romance, o que me faltava eram certas formas para poder dizê-lo. E para isso escrevi os contos: exercícios sobre diversos temas, às vezes pouco desenvolvidos, buscando soltar a mão, encontrar a forma do romance".

5 Quanto ao término da revolução, não há consenso entre os historiadores. Alguns apontam o ano de 1917, com a proclamação da Constituição do México, como o final da revolução, outros defendem que o término ocorreu somente em 1920 com a presidência de Adolfo De la Huerta e outros elegem o ano de 1924, quando Plutarco Elías Calles assumiu o poder, como o ano derradeiro da revolução. Já o historiador inglês Alan Knight, da Universidade de Oxford, considera que o real término ocorreu apenas nos anos de 1940. A partir dessas diferentes datas, o que fica claro é que o processo revolucionário ainda se estendeu por algum tempo após o término dos conflitos armados.
} 
documental de la revolución"6. A afirmação de Fuentes está ancorada no fato de que Pedro Páramo possui uma forma particular de relatar a revolução mexicana, distanciando-se, sobremaneira, das obras que abordaram essa temática antes dele. Todavia, depois de 1955, continuaram a ser produzidas obras com referência ao processo revolucionário, como La región más transparente (1958) e La muerte de Artemio Cruz (1962), do próprio Carlos Fuentes; e El gran Lector (1993), de Ignacio Solares.

Ao reconhecermos a importância de Pedro Páramo no mundo das letras latino-americanas, optamos por, neste estudo, empregar essa publicação para tratar a questão do reconhecimento de uma ideologia no processo revolucionário. Pesquisadores, como Octavio Paz (1998, p. 59), chegaram a afirmar que é impossível identificar na revolução mexicana precursores ideológicos:

Distingue a nuestro movimiento la carencia de un sistema ideológico previo y el hambre de tierras. Los campesinos mexicanos hacen la revolución no solamente para obtener mejores condiciones de vida, sino para recuperar las tierras que en el transcurso de la Colonia y del siglo XIX les habían arrebatado encomenderos y latifundistas. ${ }^{7}$

Neste texto, utilizaremos o romance de Rulfo para abordar a questão ideológica da revolução, identificando elementos que nos permitem refletir sobre os acontecimentos que se desenrolaram nas terras mexicanas no início do século XX, traçando um caminho que nos possibilita entrar e sair do texto literário conectando realidade e ficção. Tal movimento, prima por uma análise que leva em conta o caráter social da obra literária, empregando uma abordagem "transdisciplinar" que integra elementos da linguística, da semiótica, da sociologia da cultura, da filosofia, da história, e de demais áreas do saber, estabelecendo uma leitura que integra a estrutura literária aos elementos extraliterários.

\section{O QUE É UMA REVOLUÇÃO?}

Antes de discutirmos a ideologia do processo revolucionário mexicano, necessitamos fazer uma breve referência ao termo "revolução" e ao seu sentido na Modernidade, uma vez que esse vocábulo, nesse período histórico, está estreitamente relacionado à ânsia de mudança e à supervalorização de futuro apregoadas pelos tempos modernos. De acordo com Habermas (2000), Hegel foi o primeiro filósofo que desenvolveu um conceito claro de Modernidade. Ele (Hegel) o aplicou inicialmente em contextos históricos, como conceito de época - os "novos tempos" são os "tempos modernos" -, estabelecendo uma correspondência entre o uso contemporâneo "do termo em inglês e francês: por volta de 1800, modern times e temps modernes” (HABERMAS, 2000, p. 09). Segundo Habermas (2000), a referência a um

\footnotetext{
6 Tradução nossa: "para sempre - e com chave de ouro - a temática documental da revolução".

7 Tradução nossa: "Nosso movimento se distingue pela carência de um sistema ideológico prévio e pela fome de terras. Os camponeses mexicanos fazem a revolução não somente para obter melhores condições de vida, mas também para recuperar as terras que, no decorrer da Colônia e do século XIX, os colonos e os latifundiários lhes tinham arrebatado”.
} 
novo tempo feita por Hegel abandonou gradativamente o sentido puramente cronológico para assumir uma significação de oposição em relação ao tempo anterior: uma época enfaticamente "nova" - o "novo", nesse caso, está intimamente associado ao futuro, ao tempo que está por vir -. Nessa perspectiva, o limiar histórico do início da Modernidade é projetado para o início de 1500, sendo marcado por três grandes acontecimentos históricos: a descoberta do "Novo Mundo"; o Renascimento e a Reforma Protestante.

A percepção da passagem temporal do homem moderno diferencia-se das concepções de outros períodos, pois os períodos históricos que antecederam a Modernidade defendiam a unidade entre o passado e o presente, enquanto a Modernidade destaca as diferenças entre o passado e o presente: o moderno não é a continuidade do passado, mas sim sua ruptura, sua negação. O presente apresenta-se "como uma transição que se consome na consciência da aceleração e na expectativa da heterogeneidade do futuro" (HABERMAS, 2000, p. 10).

Para Paz (1984, p. 50) “a idade moderna é concebida como revolucionária”. Há dois aspectos que amparam essa afirmação. O primeiro diz respeito ao significado do termo - na Modernidade, o sentido da palavra revolução foi alterado: “à significação original - giro dos mundos e dos astros - foi justaposta outra, que é agora a mais frequente: ruptura violenta da ordem antiga e estabelecimento de uma ordem social mais justa e racional" (PAZ, 1984, p. 50). A palavra "revolução" representa a concepção de história como mudança e progresso iniludível: se a sociedade não evolui espontaneamente, é necessária uma revolução para movimentá-la, destruindo o passado e o presente e instaurando outro tempo.

O segundo aspecto diz respeito à concepção de futuro adotada pela Modernidade:

Se o homem é história e só na história se realiza; se a história é tempo lançado para o futuro e o futuro é o lugar de eleição da perfeição; se a perfeição é relativa ao futuro e absoluta diante do passado... então o futuro se transforma no centro da tríade temporal: é o imã do presente e a pedra de toque do passado. (PAZ, 1984, p. 51)

Concebido dessa forma, o futuro está para além da história. É o tempo que nunca se concretiza; é simultaneamente a projeção do tempo sucessivo e a sua negação: "A supervalorização da mudança contém a supervalorização do futuro: um tempo que não é" (PAZ, 1984, p. 52). Thomas Paine (1792 apud ALMOND, 2003, p. 11) descreveu as revoluções como pausas abruptas na continuidade histórica:

O que anteriormente chamávamos de revoluções pouco mais eram que uma mudança de pessoas. Mas o que vemos agora no mundo, a partir das revoluções na América e na França, são renovações da ordem natural das coisas em um sistema de princípios tão universal quanto a verdade e a existência do homem, combinando felicidade moral e política com prosperidade nacional.

A ideia de progresso era um importante elemento para o êxito de uma revolução. No entanto, não era o único. As revoluções ocorriam quando a ordem estabelecida havia perdido a direção, mas ainda não havia uma nova ordem capaz de substituí-la. A pobreza sozi- 
nha, como aponta Almond (2003, p. 125), "não causa inquietação", porém o sentimento de injustiça que a grande riqueza adquirida por poucos, através da revolução industrial, estava fomentando entre a maioria pobre e a complacência e a corrupção abomináveis de governantes que eram indiferentes aos sentimentos do povo eram motivos relevantes para desencadear a revolução. Nesse viés, é adequado considerarmos que todo processo revolucionário moderno traz, de forma intrínseca, o desejo de mudança e uma projeção de realização de seus ideais no tempo futuro.

\section{REVOLUCIONÁRIO, QUAL A IDEOLOGIA DA SUA REVOLUÇÃO?}

Como vimos no item anterior, toda a revolução almeja abandonar o passado e construir um futuro no qual impere uma ordem social mais justa. A partir dessa constatação, podemos afirmar que todo processo revolucionário estabelece de antemão as modificações que pretende alcançar, pois se estas não estiverem claras não há como definir o que deve ser alterado e o que deve ser mantido. Nesse caso, intrinsicamente ao processo, devemos encontrar as ideologias que motivam os anseios de mudança. No que diz referência à revolução mexicana, ao que parece, não há um consenso entre os estudiosos sobre quais ideologias a nortearam e menos ainda sobre o fato dessas ideologias terem existido ou não.

O México foi o primeiro país a vivenciar um processo revolucionário no século XX: "para surpresa geral, o México é sacudido pela primeira revolução do século XX. Envolvendo todas as classes sociais numa guerra civil que levou à morte 1 milhão de mexicanos; a etapa armada só se concluiu com a destruição do Estado porfirista e a construção de novo Estado" (VILLA, 1993, p. 08). Além do pioneirismo, a revolução mexicana carregou consigo outro selo que a diferenciava das demais lutas intraoligárquicas latino-americanas: embora, no início, a hegemonia pertencesse aos liberais, ao longo da revolução os camponeses deixaram de ser simplesmente uma classe-apoio da burguesia e apresentaram seu projeto de revolução.

Ao percebermos a história como algo que inter-relaciona o passado, o presente e as perspectivas de futuro construídas pela sociedade, consideramos que o processo revolucionário que se instaurou no México em 1910 tem suas raízes espalhadas ao longo de toda a história desse país. Paz (1998) também adota essa percepção para discutir o que sucedeu a partir de 1910 no cenário mexicano. Ele faz um retorno ao processo de independência da América Espanhola como um dos pontos que deve ser considerado para compreender por que o México apresentou a primeira revolução do século XX. Segundo ele, o processo de independência separou as colônias da ex-metrópole o que permitiu a criação de uma série de países recém-independentes. No México, os independentistas foram incapazes de criar uma sociedade moderna, diferentemente do que aconteceu em outros países latino-americanos que, mesmo sem promover alterações profundas na sociedade, fizeram um empreendimento de caráter modernizador. Nesse país, instaurou-se uma sociedade agrária que era dominada por uma nova casta latifundiária. A burguesia era uma classe pequena instalada nos centros urbanos, enquanto os latifundiários, no meio rural, tinham o poder de decisão. Foi esse Estado que Porfírio Díaz governou por mais de trinta anos. O governo de Díaz foi 
marcado por perseguições políticas, pelo uso da violência, mas também por um projeto que se mostrou incapaz de (ou desinteressado em) alterar a face semicolonial mexicana. Porfírio Díaz:

Suprime la anarquía, pero sacrifica la libertad. Reconcilia a los mexicanos, pero restaura los privilegios. Organiza el país, pero prolonga un feudalismo anacrónico e impío, que nada suavizaba (las Leyes de Indias contenían preceptos que protegían a los indios). Estimula el comercio, construye ferrocarriles, limpia de deudas la Hacienda Pública y crea las primeras industrias modernas, pero abre las puertas al capitalismo angloamericano. En esos años México inicia su vida de país semicolonial. ${ }^{8}$ (PAZ, 1998, p. 54)

Díaz foi incapaz de trazer o progresso que era esperado, perpetuando estruturas coloniais - agora mascaradas pela adoção de elementos e técnicas modernos - sem uma perspectiva positiva de futuro. Ele, em aparência, governava inspirado pelas ideias que estavam em voga, ou seja, os ideais da burguesia europeia: acreditava no progresso, na ciência, nos milagres da indústria e do livre comércio. Esses ideais, entretanto, eram desfavoráveis aos campesinos: a propriedade da terra se concentrava nas mãos de alguns latifundiários que se fortaleciam cada vez mais enquanto os campesinos tornavam-se mais pobres e dependentes. A realidade que se apresentava trazia poucas perspectivas. Nesse quadro, a revolução surgiu como uma resposta à situação mexicana do início do século XX.

Para Octavio Paz, a revolução de 1910 não apresentava um sistema ideológico prévio e, para dar conta dessa ausência, foi adotado um programa liberal que se mostrava compatível com o período vivenciado. Para Paz (1998), a revolução apresentou-se como um resgate do passado mexicano anterior à Reforma e ao governo de Porfírio Díaz, sem contemplar planos futuros (algo que é essencial para o processo revolucionário):

La revolución apenas si tiene ideas. Es un estallido de la realidad: una revuelta y una comunión, un trasegar viejas sustancias dormidas, un salir al aire muchas ferocidades, muchas ternuras y muchas finuras ocultas por el miedo a ser. ¿Y con quién comulga México en esta sangrienta fiesta? Consigo mismo, con su propio ser. México se atreve a ser. La explosión revolucionaria es una portentosa fiesta en la que el mexicano, borracho de sí mismo, conoce al fin, en abrazo mortal, al otro mexicano. ${ }^{9}$ (PAZ, 1998, p. 62)

\footnotetext{
8 Tradução nossa: "Suprime a anarquia, mas sacrifica a liberdade. Reconcilia os mexicanos, mas restaura os privilégios. Organiza o país, mas prolonga um feudalismo anacrônico e ímpio, que em nada suavizava (as Leis de Índias continham preceitos que protegiam os índios). Estimula o comércio, constrói indústrias modernas, mas abre as portas ao capitalismo anglo-americano. Nesses anos o México inicia sua vida de país semicolonial".

9 Tradução nossa: “A revolução mal tem ideias. É um estouro de realidade: uma revolta e uma comunhão, um remexer de velhas substâncias adormecidas, um vir à tona de muitas ferocidades, muitas ternuras e muitas delicadezas ocultas pelo medo de ser. E com quem comunga o México nesta festa sangrenta? Consigo mesmo, e com seu próprio ser. O México se atreve a ser. A explosão revolucionária é uma festa portentosa em que o mexicano, bêbado de si mesmo, conhece ao fim, no abraço mortal, a outro mexicano".
} 
Paz (1998) defende a ideia de uma revolução espontânea, de um acontecimento que se fez necessário ao longo da história, mas que não contava com um planejamento adequado nem mesmo uma efetiva tomada de consciência do contexto histórico-social. Essa percepção, todavia, é criticada por Arnaldo Córdova, em La revolución y el Estado en Mexico (1989). Córdova (1989) também critica o fato de que a revolução ocorrida no México constituiu-se como um fato isolado no mundo, não possuindo inspiradores nem par em nenhuma outra revolução. A revolução mexicana:

(...) fue un gran debate ideológico en el que no sólo se puso en discusión nuestro ser nacional, el sentido de nuestra historia, la organización y la composición de nuestra sociedad, la idea del gobierno de la misma, las injusticias que prevalecían en la organización social, el tipo de desarrollo económico, político y cultural que debía promoverse, las clases sociales y los componentes étnicos de la sociedad mexicana, el sistema nacional de relaciones de propiedad y de producción, los valores a los cuales se debían los mexicanos y aquellos que debían sobresalir para consumar nuestra formación nacional. ${ }^{10}$ (CÓRDOVA, 1989, p. 56)

De acordo com Córdova, a linha ideológica passou a ser traçada com a crítica ao Estado criado por Porfírio Díaz. A forma de governar de Díaz havia salientado as diferenças sociais, criando um país para poucos. A grande maioria da população não estava satisfeita e almejava melhores condições de vida e menos exploração do trabalho. Tais reivindicações constituem, na visão de Córdova, alguns dos pontos que formaram a base ideológica revolucionária. Entre os ideólogos cujas ideias pontuaram o processo revolucionário mexicano, Córdova (1989) destaca três: Andrés Molina Enriquéz, Ricardo Flores Magón e Francisco Madero. Vejamos cada um deles em particular.

O primeiro, Andrés Molina Enriquéz (1868-1940), foi um advogado, sociólogo e escritor mexicano de ideologia positivista que pensou a relação do Estado com o desenvolvimento da economia camponesa. Enríquez, durante as primeiras décadas do século XX, escreveu textos de caráter sociológico que tinham como intuito apresentar ("diagnosticar") os problemas da sociedade mexicana, como as profundas desigualdades sociais, a má distribuição e utilização da terra, a ausência de integração entre as diferentes regiões do país, as ameaças à soberania nacional, a inexistência de uma consciência nacional e a desvalorização da cultura nacional, iniciando no México um movimento de análise crítica do Porfiriato. Sua publicação mais marcante foi Los grande problemas nacionales (1978), datada do ano de 1908. A influência dessa obra foi tão grande no cenário mexicano que motivou outros pensadores a publicarem obras de crítica ao Porfiriato, tais como ¿Hacia dónde vamos?, de Querido Moheno, Cuestiones electorales, de Manuel Calero, La reelección indefinida,

\footnotetext{
10 Tradução nossa: “(...) foi um grande debate ideológico no qual não somente foi posto em discussão nosso ser nacional, o sentido de nossa história, a organização e a composição de nossa sociedade, a ideia de governo da mesma, as injustiças que prevaleciam na organização social, o tipo de desenvolvimento econômico, político e cultural que devia promover-se, as classes sociais e os componentes étnicos da sociedade mexicana, o sistema nacional de relações de propriedade e de produção, os valores aos quais se deviam os mexicanos e aqueles que deviam sobressair para consumar nossa identidade nacional".
} 
de Emilio Vázquez Gómez, e La sucesión presidencial en 1910, de Francisco Madero. Além disso, surgiram novos jornais que se mostravam contrários ao governo e novos partidos políticos começaram a se organizar.

Enriquéz (1978) defendia a elaboração de um projeto de política nacional que buscasse solucionar os problemas econômicos e sociais do país ao mesmo tempo em que fosse capaz de despertar um espírito nacional forte. Ele pensava a nação como um organismo cujo desenvolvimento dependia da evolução e da ação integrada de suas partes, constituídas pelos diversos setores da população nacional. Ao Estado caberia o papel de grande cérebro do organismo nacional, garantindo e estimulando as ações coordenadas das diferentes partes.

Após a queda do governo Díaz e a ascensão ao poder do Madeirismo, Enríquez continuou defendendo a necessidade de transformações na estrutura socioeconômica do país para que os problemas diagnosticados realmente fossem solucionados. Como Enríquez não encontrasse no governo de Madero as atitudes que esperava, rompeu com o novo chefe de Estado e tomou a ação direta por meio do Plano de Texcoco, em julho de 1911, no qual defendia, principalmente, o fracionamento dos latifúndios maiores de 2000 hectares; a vigência dos contratos de trabalho e do pagamento por antecipações. Tal posicionamento implicou em sua prisão até março de 1912. Mesmo preso, Enriquéz seguiu publicando suas ideias de reforma agrária no Diario del Hogar.

Os rumos que a revolução mexicana tomou acompanhados pela pressão dos setores populares para que o Estado concentrasse maiores poderes (sendo responsável por implementar as reformas sociais aspiradas) tornaram as ideias de Enriquéz uma fonte de inspiração para vários grupos revolucionários, incluindo o grupo conduzido por Venustiano Carranza. Durante o governo de Carranza, em 1916, Andrés Molina Enríquez foi nomeado membro consultor da Comissão Nacional Agrária, do Ministério da Agricultura e Fomento, sendo responsável pela redação do projeto do Artigo 27 constitucional. Tal artigo tratava de assuntos como o direito do Estado à expropriação das terras em benefício público, o subsolo como propriedade do Estado e sua exploração para o bem público e o reconhecimento das comunidades indígenas sobre as terras de uso comum.

Já Ricardo Flores Magón (1873-1922) foi um jornalista, escritor e político que defendia a liberdade, o fim do autoritarismo e a democracia: "Flores Magón ve todos los hechos sociales a través del prisma del individuo libre" ${ }^{11}$ (CÓRDOVA, 2003, p. 173). Nascido de uma família de tradição liberal, já, em 1892, Magón havia participado das manifestações estudantis contra a terceira reeleição de Porfirio Díaz. Naquele mesmo ano, começou a colaborar como jornalista no periódico de oposição El Demócrata. No ano de 1900, Ricardo Flores Magón, junto com seu irmão mais velho (Jesús Flores Magón), fundou o jornal jurídico Regeneración, onde criticavam a corrupção do sistema judicial do regime ditatorial de Porfirio Díaz. Por conta das publicações feitas no Regeneración, Ricardo foi preso. Depois de sair da prisão, em 1902, assumiu a direção do jornal satírico El Hijo del Ahuizote, no qual seguiu manifestando sua opinião política. Nos artigos publicados nesses dois periódicos (Regeneración e El Hijo del Ahuizote), podemos encontrar a amostra mais significativa de seu pensamento político.

11 Tradução nossa: "Flores Magon ve todos os acontecimentos sociais através do prisma do individuo livre". 
Magón (1970) compreendia os problemas das massas a partir de uma concepção de justiça na qual o valor da liberdade individual é o verdadeiro centro de ação. É possível perceber que esse jornalista apresentava clara percepção das necessidades dos diferentes segmentos da população mexicana e que as defendia com determinação, todavia não possuía identificação com estas:

Porque si bien acepta que son objeto de toda la injusticia que en mundo existe, jamás las ve como sujetos capaces de liberarse a sí mismos; las masas no constituyen para el revolucionario oaxaqueño un elemento positivo, sino el resultado de la falta de libertad, el resumen de la esclavitud de los hombres; por eso las transciende y las disuelve en la crítica del sistema social. ${ }^{12}$ (CÓRDOVA, 2003, p. 173)

Magón (1970) defendia que o problema das massas era também o problema da liberdade, uma vez que o lugar da massa deve ser ocupado pelos indivíduos livres, conscientes de sua própria individualidade e de sua própria liberdade: essa sempre foi a motivação do revolucionário, embora os motivos que a orientaram nem sempre tenham sido os mesmos. No ano de 1906, quando foi publicado o Programa del Partido Liberal ${ }^{13}$, Magón defendia, como todos os liberais, um governo democrático firme e respeitador das leis para que os homens fossem livres. Nos anos seguintes, Magón percebeu que um bom governo não é suficiente para efetivar a liberdade dos cidadãos e que, inclusive, a própria existência do governo era um empecilho para alcançar a efetiva liberdade. Por conta disso, as ideias defendidas por ele, depois de 1906, deixaram de se constituir como precursoras da revolução mexicana, se considerarmos o desfecho que esta obteve. Magón tornou-se um anarquista libertário. Depois do término da revolução mexicana e da morte de Ricardo Flores Magón (1922), as ideias deste foram retomadas por um considerável número de libertários, principalmente por sindicalistas no México e nos Estados Unidos. Tais ideias receberam o nome de "Magonismo", sendo, atualmente, consideradas como uma vertente anarquista.

O terceiro nome que destacaremos neste texto é do empresário e político mexicano Francisco Madero (1873-1913), cuja contribuição foi de suma relevância para que a revolução ocorresse. Em 1905, Madero teve contato com a Junta Organizadora del Partido Liberal Mexicano, a qual apoiou economicamente para retomar a edição do jornal Regeneración. Entretanto, devido às diferenças ideológicas com Ricardo Flores Magón, retirou seu apoio ao Partido Liberal Mexicano.

Em 1908 (mesmo ano da publicação de Los grande problemas nacionales, de Andrés Molina Enriquéz), escreveu e publicou o livro La sucesión presidencial en 1910. De acordo com Córdova (2003), esse livro foi de grande importância no cenário mexicano, conver-

\footnotetext{
12 Tradução nossa: "Porque, se aceita que são objeto de toda a injustiça existente no mundo, não as vê como sujeitos capazes de libertarem-se a si mesmos; as massas não constituem para o revolucionário oaxaquenho um elemento positivo, mas sim o resultado da falta de liberdade, o resumo da escravidão dos homens; por isso as transcende e as dissolve na crítica do sistema social".

13 O Programa del Partido Liberal Mexicano foi publicado em $1^{\circ}$ de julho de 1906, pela Junta Organizadora, em San Luis, Missouri, através do periódico Regeneración. Esse Programa agrupou dezenas de organizações liberais contrárias à ditadura de Porfírio Díaz.
} 
tendo seu autor no homem que faltava para que a revolução se desencadeasse. La sucesión presidencial en 1910 critica o governo de Porfírio Díaz, reivindicando a realização de eleições justas e transparentes, com a intenção de tornar o México um Estado democrático, moderno e com eleições livres.

Madero (1960) considerava que o povo mexicano estava preparado para promover as transformações que o país necessitava através da via democrática. O povo deveria lutar pela divisão dos latifúndios, democratizar a posse de terras, enfim, agir em prol das mudanças necessárias. Ao contrário de Molina que defendia uma atuação violenta do Estado para que os grandes latifúndios fossem divididos, Madero era contra uma solução autoritária para a crise social.

Madero chegou à presidência em 1911. Sua vocação pacifista levou-o a aceitar o interinato de Francisco León de la Barra, durante o qual os grupos revolucionários foram reprimidos, especialmente os zapatistas. A instabilidade social e política e o descontentamento com seu governo foram constantes. Ele recebia críticas dos antigos porfiristas e dos grupos revolucionários, uma vez que ambos opunham-se ao seu plano conciliador, cuja meta era estabelecer uma democracia com partidos políticos e impedir a reeleição. Dessa forma, não conseguiu consolidar seu governo. Em 13 de fevereiro de 1913, foi assassinado por ordem de Victoriano Huerta.

Como pudemos perceber, ao contrário das considerações de Octavio Paz, a revolução mexicana foi um movimento constituído com bases ideológicas, sendo estas as motivadoras e as estruturadoras do processo revolucionário. Embora não seja possível contar com nomes de grandes intelectuais na condição de líderes do movimento, é possível defender que a revolução não apresentou uma ideologia única, mas sim várias ideologias, cujos propósitos entrelaçavam-se em certa medida e distanciavam-se em outra, mas que foram capazes de sustentar as mobilizações ao longo de todo o México e de envolver o povo nos confrontos. Nos escritos desses três senhores, encontramos as bases ideológicas que inspiraram o inicio dos confrontos em 1910. Os embates que se seguiram contaram com o engajamento de diversos setores da sociedade mexicana. E, embora seja um fato que muitos revolucionários participaram dos confrontos por interesses particulares ou mesmo apenas belo bulício, o que desencadeia os primeiros conflitos e norteia os confrontos que se sucederam nos anos posteriores a 1910 pode ser reconhecido, principalmente, na figura desses três nomes que são destacados por Córdova (2003).

Um dos aspectos que talvez tenha motivado Paz a considerar a ausência de ideologias no movimento (além da falta de nomes de intelectuais de destaque) se deve ao fato de que muitos grupos revolucionários ingressaram nos confrontos em busca de vinganças pessoais (levantando armas contra latifundiários e governantes específicos, e não contra a estruturação econômica e social mexicana), ou apenas pelo bulício (promovendo roubos, agressões, assassinatos, violações de mulheres, etc.). Os caudilhos eram vistos com desconfiança por alguns segmentos populacionais; a violência dos camponeses, que queimavam bibliotecas, também desagradava à população, salientando que a revolução não podia ser tomada como um todo uniforme e organizado.

Arceo (2011, p. 66) expõe, no texto "El perro del oficial Tarre", alguns dos problemas ocasionados pelos grupos que aproveitaram o momento para realizarem atos reprováveis 
sem serem punidos, pois acobertavam-se sob a insígnia de "revolucionários": "El avance revolucionario continuaba y cada día se reportaban saqueos y asesinatos que poco tenían que ver con demandas políticas; el movimiento rebelde estaba dando pie a que la 'caballada' se desbocara al vandalismo y la rapiña" ${ }^{14}$. Choubey (2011) também faz referência aos roubos cometidos por alguns grupos - "mediante las acciones propias de los revolucionarios se manifiesta que la revolución les sirvió a muchos para robar, o más bien como aventura"15 (CHOUBEY, 2011, p. 113).

Através dos três nomes selecionados por Córdova (2003), percebemos que a revolução teve um forte vínculo com a ideologia liberal ou liberalismo - ao contrário da afirmação de Paz (1998) que defende que a revolução apenas valeu-se de tais ideais por não encontrar a oferta de outra proposta. Mas, o que nem Córdova nem Paz discutem de forma apropriada é o motivo pelo qual essas propostas foram recebidas de forma fértil no cenário mexicano e a vinculação destas com a Modernidade. Segundo Wallerstein (1996, p. 22), "el liberalismo se levantó como respuesta al conservadurismo, y como la doctrina de los defensores de la Modernidad que buscaban conseguir su pleno florecimiento de manera metódica"16. O liberalismo nasceu após a revolução burguesa, inspirado por pensadores como John Locke e Adam Smith. Em suas bases podemos destacar: o livre uso, por cada membro da sociedade, de sua propriedade; todos os homens são iguais perante a lei; a promoção do bem comum. Esses ideais são encontrados nas propostas de Andrés Molina Enriquéz, Ricardo Flores Magón e Francisco Madero. Contudo, o ganho obtido com o emprego dessas concepções em solo mexicano está na forma como o povo é percebido. Enquanto o liberalismo visava à dominação dos trabalhadores de forma consentida, através da identificação dos interesses da classe dominante com o interesse da sociedade em sua totalidade (Nação) ${ }^{17}$, no cenário mexicano buscava-se uma equiparação na ordem social e o reconhecimento de uma identidade nacional.

As bases ideológicas que sustentaram a revolução, o estabelecimento de uma crítica concreta contra o governo, a voz do povo que se fez ouvir, nada mais são do que reflexo da constituição de um pensamento moderno no cenário mexicano. O próprio processo revolucionário, como destacamos anteriormente, também é filho da Modernidade. Assim, engana-se Paz (1998) quando afirma que a revolução mexicana não possui precedentes, porque ela os possui. Seus precedentes são toda a estrutura histórica que estava desenvolvendo-se ao redor do mundo; seus precedentes estão no pensamento crítico, na proposição de novas ideologias e de novas concepções de Estado, de governo, de povo. Então, podemos afirmar que a revolução mexicana não possui nada de novo? Ao contrário. A revolução no México

\footnotetext{
14 Tradução nossa: "o avanço revolucionário continuava e cada dia se reportavam saques e assassinatos que pouco tinham que ver com demandas políticas; o movimento rebelde estava dando pé a que a 'cavalaria' desembocasse no vandalismo e no roubo".

15 Tradução nossa: "mediante as ações próprias dos revolucionários se percebe que a revolução serviu a muitos para roubar, ou ainda como uma aventura".

16 Tradução nossa: "o liberalismo ergueu-se como resposta ao conservadorismo, e como a doutrina dos defensores da Modernidade que buscavam conseguir seu pleno florescimento de forma metódica”.

17 O povo que não fazia parte da classe dominante era visto como as "classes perigosas", pois ameaçavam a ordem instaurada pelo Estado.
} 
foi o sinal de um novo período que se delineava na América Latina; foi a efetiva assunção das concepções modernas.

\section{CONSIDERAÇÕES SOBRE A IDEOLOGIA REVOLUCIONÁRIA EM PEDRO PÁRAMO}

Pedro Páramo apresenta-nos a história de um filho (Juan Preciado) que, após a morte da mãe (Dolores Preciado), parte para um povoado (Comala) em busca de seu pai (Pedro Páramo). Juan, filho de um casamento legítimo, fora criado longe do pai em virtude dos desentendimentos ocorridos entre o casal Pedro e Dolores, motivando esta a abandonar Comala. Cheio de esperanças, Preciado inicia sua viagem na tentativa de encontrar elementos que o ajudem a compor a parte paterna de sua identidade. Entretanto, seu pai já está morto e o que resta ao filho de Dolores é um povoado em ruínas ocupado pelos fantasmas de todos aqueles que sucumbiram ante o jugo de Pedro Páramo.

Durante a segunda noite que passou em Comala, sufocado pelas vozes dos mortos, tomado pelo pânico, Juan Preciado sofreu uma parada cardíaca e faleceu, passando a integrar o grupo de mortos presos ao povoado. Enquanto estava vivo, ele escutou dos mortos histórias sobre Comala que o ajudaram a conhecer parte do passado desta e, por conseguinte, parte do passado de seu pai. Depois de sepultado, Juan seguiu ouvindo relatos, dessa vez eles provinham de duas mulheres que estavam próximas a ele: Dorotea (estava sepultada ao seu lado ou encontrava-se na mesma cova - o texto não é claro sobre isso) e Susana San Juan (que sepultada próximo a Juan e Dorotea, enuncia alguns monólogos). Além das vozes de Susana e Dorotea, há um narrador em terceira pessoa que conta como os homens de Comala entraram na revolução, como o cura ingressou na Guerra Cristera e como Abundio (irmão de Juan Preciado por parte de pai) matou Pedro. Tais ações são os elementos que selam o destino de Comala que, abandonada por Pedro desde a morte de Susana Sam Juan, vê sua história assumir um rumo de ruína e condenação.

O narrador em terceira pessoa pode ser considerado como o somatório das vozes dos mortos de Comala que assumem a autonomia da narração que Juan havia principiado. Os fatos que os mortos narram marcam um momento de transição para o povoado: ocorre a decadência de um sistema oligárquico, cujo elemento representativo é Pedro Páramo, para o nascimento de uma nova forma de organização social e econômica. Uma associação com o período da revolução mexicana é pertinente para compreendermos essa transição. Pedro Páramo, com suas grandes propriedades, é o exemplo de oligarca que lucra com o trabalho do povo. Ele fazia suas leis e comandava o povoado de acordo com sua vontade. Com o processo revolucionário, Pedro viu seu poder ser ameaçado. E, para evitar grandes prejuízos, infiltrou alguns de seus homens entre os grupos de revolucionários e deu-lhes dinheiro na condição de manter suas propriedades seguras e intactas.

É possível perceber uma perspectiva crítica na narrativa quanto ao processo revolucionário e a forma como este foi conduzido. Não são as vozes dos mortos que criticam a revolução; elas parecem não ter uma real consciência do que tal processo acarretou e de como ele desenvolveu-se de fato. A crítica é feita através dos diálogos entre Pedro e seus empregados, sendo esses apresentados por um narrador em terceira pessoa. Tilcuate, empregado 
de Pedro, é infiltrado por este nas manifestações revolucionárias. O que mais atrai Tilcuate no processo é o bulício, não a luta pela melhoria do país ou a defesa de alguma ideologia. Sequer os revolucionários que buscaram Pedro tinham claro os motivos pelos quais haviam ingressado na revolução: “¿Pero por qué lo han hecho?/ - Pos porque otros lo han hecho también. ¿No lo sabe usté? Aguárdenos tantito a que nos lleguen instrucciones y entonces le averiguaremos la causa. Por lo pronto ya estamos aquí"18 (RULFO, 2009a, p. 103). Ao escutar isso, um integrante do grupo respondeu: “-Yo sé la causa - dijo otro -. Y si quiere se la entero. Nos hemos rebelado contra el gobierno y contra ustedes porque ya estamos aburridos de soportarlos. Al gobierno por rastrero ya ustedes porque no son más que unos móndrigos bandidos y mantecosos ladrones" ${ }^{19}$ (RULFO, 2009a, p. 103). As causas da revolta não são claras para muitos revolucionários, os quais, pelas oportunidades de roubo e de violência, foram atraídos para os grupos armados. Nesse caso, os ideais revolucionários pouco ou nada importam e a invasão de terras, os saques e a violação de mulheres são o maior ganho. Para outros, os enfrentamentos surgem como oportunidades de vingança pessoal, como uma chance de retaliar os anos de subjugação e de domínio impostos por latifundiários como Pedro Páramo. Nesse caso, qualquer vantagem adquirida durante os confrontos é vista como positiva, seja a morte do latifundiário ou a aquisição de algum bem material.

Tal construção narrativa leva-nos a considerar que, em Pedro Páramo, encontramos a mesma perspectiva relacionada à ideologia revolucionária que havíamos encontrado em Octavio Paz: a revolução não apresenta uma base ideológica. No entanto, a partir das discussões que já estabelecemos neste texto, podemos realizar uma leitura a partir da qual a crítica presente no texto não se deve à ausência de uma base ideológica, mas sim ao fato de que muitos grupos ingressaram na batalha sem terem essa base clara, sendo motivados por ideais distintos daqueles que eram apregoados pelo movimento revolucionário. No romance há uma crítica a esses grupos que acabam por ser enganados e manipulados por Páramo. Mas, dado ao desfecho que acomete o pai de Juan Preciado, parece-nos que o processo revolucionário triunfa, pondo fim ao sistema oligarca e aos benefícios concedidos aos grandes latifundiários. Ao apresentar um resgate da história de Comala, a narrativa rulfiana oferece uma série de motivos que justificariam uma luta por mudanças. Esses motivos são apresentados em uma escala reduzida, estando atrelados à vida em Comala. Contudo, podem ser ampliados, uma vez que os confrontos estendem-se para além de Comala.

O grupo comandado por Tilcuate sustentava-se através dos benefícios que conseguia dos grandes latifundiários e, em troca, não os molestava, ou seja, era um grupo corrupto em sua essência. Ao longo do processo revolucionário, Tilcuate muda de lado diversas vezes, seguindo os conselhos de Pedro: "Ya te he dicho que hay que estar con el que vaya ganando" 20 (RULFO, 2009a, p. 114) e "Ponte al lado del gobierno" (RULFO, 2009a, p. 124). Assim,

\footnotetext{
18 Tradução nossa: “-Por que o fizeram?/ -Pois porque outros o fizeram também. O senhor não sabe? Aguarde um pouquinho que nos chegarão instruções e então averiguaremos a causa. Para o que for, já estamos aqui”.

19 Tradução nossa: "Eu sei a causa - disse outro -. E se quiser informo. Rebelamo-nos contra o governo e contra vocês porque já estamos cansados de suportá-los. Ao governo por rasteiro e vocês porque não são mais que uns bandidos desprezíveis e ladrões sebentos".

20 Tradução nossa: "Já te disse que deve estar com aquele que estiver ganhando".

21 Tradução nossa: "Ponha-te do lado do governo".
} 
vemos no romance uma revolução na qual as personagens alegam terem se rebelado contra o governo e os grandes latifundiários (discurso base dos revolucionários mexicanos), mas que atuam entre essas duas esferas, não rompendo verdadeiramente com nenhuma delas, construindo, portanto, uma imagem negativa. Dos latifundiários retiram o dinheiro e, para não sofrerem grandes derrotas, procuram manter-se ao lado do governo, mudando sempre com ele: "Villistas"; "carrancistas" ("Andamos con mi general Obregón"22 - RULFO, 2009a, p. 124). As referências aos "villistas" e aos "carrancistas" permitem uma leitura que vincula estreitamente a narrativa ao processo revolucionário mexicano, às consecutivas trocas presidenciais ao longo do período de confronto e às ideologias assumidas por esses governos.

O processo revolucionário, filho da Modernidade, buscava o progresso, o desenvolvimento da técnica, mas era também fundamentado em ideais como a liberdade e a igualdade entre os homens. Esperava-se que, com a revolução, o futuro fosse capaz de atender às necessidades dos indivíduos: o futuro configurava-se como o tempo da realização. Mas, em Pedro Páramo, o processo revolucionário, que produziu alterações na organização social e econômica do pequeno povoado, apresentou-se como um acontecimento determinante para a aniquilação gradual de Comala. Não sabemos o desfecho da revolução no romance porque esta é apresentada como um movimento rumo ao futuro, com realizações que se concretizaram depois da morte de Pedro.

\section{CONSIDERAÇÕES FINAIS}

A revolução mexicana tem um importante papel não apenas na história do México, mas também na história mundial. O fato de ter sido a primeira insurreição popular do século XX lhe atribui um papel inspirador para as demais sociedades ao redor do mundo e fato de ter reunido nos confrontos grupos originários de diversas classes sociais - possibilitando um real envolvimento de toda a nação nos conflitos - a configura como uma revolução efetivamente popular. Este último traço, contudo, tem sido o causador de certas dúvidas sobre a estrutura e a organização interna da revolução. No momento em que vários grupos viram-se reunidos lutando ao longo de todo o território nacional, cada qual carregava anseios particulares e motivos singulares para lutar. Tal fato fez com que alguns estudiosos considerassem que a revolução não possuía uma ideologia clara e definida, que os grupos lutavam de forma desordenada. Porém, como vimos ao longo deste texto, haviam propostas ideológicas que orientavam os grupos que assumiram a liderança do movimento, como, por exemplo, o grupo liderado por Madero, que alcançou a presidência ainda em 1910, tinha clara sua ideologia.

Em Pedro Páramo, encontramos uma crítica aos grupos que integraram a revolução apenas pelo bulício, sem ideais estabelecidos, sem vínculos com uma ideologia particular. Esses grupos são apresentados como corruptos, pois mudam de opinião constantemente, seguindo sempre o grupo vencedor além de equilibrarem-se entre o governo e os oligarcas, esferas contra as quais se erigiu o movimento revolucionário. A crítica no romance de Rul-

22 Tradução nossa: "Andamos com meu general Obregón”. 
fo, entretanto, não desmerece o movimento revolucionário, pois este conseguiu pôr fim ao estado oligárquico que imperava em Comala. Porém, o preço pago por essa vitória é demasiadamente alto, uma vez que sem a força de trabalho dos homens no povoado, Comala definhou e morreu, convertendo-se em uma cidade fantasma, habitada pelo espectro daqueles que um dia nela viveram. O desfecho de Pedro Páramo, com a morte do tirano, remete ao triunfo dos ideais revolucionários e ao surgimento de uma nova era no México, enquanto a morte do povoado referencia as inúmeras perdas ocasionadas pelos confrontos.

Neste texto transitamos entre o posicionamento de Octávio Paz e o posicionamento de Arnaldo Córdova sobre a existência ou não de uma ideologia na revolução mexicana. Os dois pontos de vista, ainda que opostos, nos ajudaram a concretizar uma proposta de leitura do romance rulfiano que considera a entrada na revolução de diversos grupos sociais, com interesses distintos entre si e, por conta disso, com a assunção de ideologias diferentes ou mesmo sem a adoção de uma ideologia.

\section{REFERENCIAS BIBLIOGRÁFICAS}

ALMOND, Mark. O livro de ouro das Revoluções. Tradução de Gilson Batista. Rio de Janeiro: Ediouro, 2003.

ARCEO, Sandra Molina. El perro del oficial Tarre. In: ROSAS, Alejando (Coord.). Las dos caras de la historia: Revolución Mexicana: El tiempo del caos. Cidade do México: Grijalbo, 2011. p. 53 - 77.

CHOUBEY, Chandra Bhushan. Juan Rulfo: El llano sigue en llamas y las ánimas en pena. Cidade do México: Tecnológico Monterrey; Miguel Ángel Porrua, 2011.

CÓRDOVA, Arnaldo. La ideología de la Revolución Mexicana: La formación del nuevo régimen. Cidade do México: Ediciones Era, 2003.

La Revolución y el Estado en México. Cidade do México: Ediciones Era, 1989.

ENRÍQUEZ, Andrés Molina. Los problemas nacionales (1909, y otros textos, 1911-1919). Cidade do México: Ediciones Era, 1978.

FUENTES, Carlos. La nueva novela hispanoamericana. Cidade do México: Cuadernos de Joaquín Mortiz, 1980.

GARCÍA, Édgar D. Rojano. Emiliano Zapata, contra todo y contra todos. In: ROSAS, Alejando (Coord.). Las dos caras de la historia: Revolución Mexicana: El tiempo del caos. Cidade do México: Grijalbo, 2011.p. 107 - 140.

HABERMAS, Jürgen. O discurso filosófico da modernidade: doze lições. Tradução de Luiz Sérgio Repa e Rodnei Nascimento. São Paulo: Martins Fontes, 2000. 
MADERO, Francisco. La sucesión presidencial en 1910. Cidade do México: Ediciones de la Secretaría de Hacienda, 1960.

MAGÓN, Ricardo Flores. La Revolución Mexicana. Cidade do México: Editorial Grijalbo, 1970.

PAZ, Octávio. El laberinto de la soledad. Madrid: Fondo de Cultura Económica de España, 1998.

Os filhos do barro: do romantismo à vanguarda. Tradução de Olga Savary. Rio de Janeiro:

Nova Fronteira, 1984.

RULFO, Juan. Pedro Páramo. Santiago de Chile: Editorial RM, 2009a.

El llano en llamas. Santiago de Chile: Editorial RM, 2009b.

Juan Rulfo: La literatura es una mentira que dice la verdad. Una conversación con Ernesto Gonzalez Bermejo. Entrevista concedida a Ernesto Gonzalez Bermejo. In: Fell, Claude (Coord.). Juan Rulfo. Toda la obra. Edición crítica. $2^{a}$ ed. Madrid, París; Cidade do México; Buenos Aires; São Paulo; Rio de Janeiro; Lima: ALLCA XX, 1996.

VILLA, Marco Antonio. A Revolução Mexicana. São Paulo: Editora Ática, 1993.

VITAL, Alberto. Notícias sobre Juan Rulfo. Cidade do México: Editorial RM, 2003.

WALLERSTEIN, Immanuel. El fin de ¿qué modernidad? La Época, Costa Rica, 20 out. 1996. p. 22-23 